\title{
Daily ration estimates and comparative study of food consumption in nine species of deep-water decapod crustaceans of the NW Mediterranean
}

\author{
Francesc Maynou ${ }^{1, *}$, Joan E. Cartes ${ }^{1,2}$ \\ ${ }^{1}$ Institut de Ciències del Mar, CSIC, Pg. Joan de Borbó s/n, E-08039 Barcelona, Spain \\ ${ }^{2}$ Institut Mediterrani d'Estudis Avançats, Ctra. de Valldemossa km 7,5, E-07071 Palma de Mallorca, Spain
}

\begin{abstract}
Estimates of the daily ration consumed by 9 species of decapod crustaceans were obtained from 2 deep-water samplings over the middle and lower continental slope of the NW Mediterranean. The daily rations obtained varied by an order of magnitude from the slow-moving, crab-like species $(<0.1 \mathrm{~g}$ dry food per $100 \mathrm{~g}$ predator body weight) to the actively swimming mesopelagic shrimps $(>1.0 \mathrm{~g}$ dry food per $100 \mathrm{~g}$ predator body weight). A multivariate analysis allowed us to relate the variability in daily ration estimates to the functional morphology and ecology of the species considered. The functional morphology and ecology of the species studied are defined ın terms of body shape, swimming capability, trophic diversity and spatial distribution. We found that body shape (ratio of carapace length to carapace width) and trophic diversity $\left(H^{\prime}\right)$ account for most of the variability in the amount of food consumed by dercapods. The food consumption pattern established for our decapod crustaceans is compared to a similar pattern reported for deep-water fishes
\end{abstract}

KEY WORDS: Daily ration - Decapod crustaceans - Feeding ecology - Deep-sea ecology

\section{INTRODUCTION}

In the NW Mediterranean, decapod crustaceans form a considerable fraction of the megafaunal biomass, around 40\% (Cartes et al. 1994a), over the middle and lower continental slope. They play a key role in deep-water Mediterranean communities, as they are the main link between macrofauna and megafaunal top predators, such as fish (Gage \& Tyler 1991, Cartes \& Sardà 1992, Cartes 1998). The diets and food resources of decapods have been extensively studied in the NW Mediterranean (Cartes \& Abello 1992, Cartes 1993a, b, 1994) but quantitative studies of daily ration for decapods under natural conditions are generally lacking

Food consumption in megafaunal species is typically investigated by daily ration methods. These methods were originally developed for finfish species (Durbin et

•E-mail: maynouf@icm.csic.es al. 1983, Worobec 1984, Macpherson 1985, Bulman \& Koslow 1992, Pakhomov et al. 1996), and the methodology is now well established, both in the laboratory and in the field. Maynou \& Cartes (1997) extended this methodology to decapod crustaceans with a case study of the deep-water penaeid shrimp Aristeus antennatus, a highly abundant and commercially important species in the NW Mediterranean. These authors produced an estimate of food consumption for A. antennatus based on field measurements, given that the application of daily ration methods based on animals reared in the laboratory is not possible in deep-sea studies due to the practical difficulties of keeping deep-sea fauna alive in the laboratory, and that field determinations of daily ration are preferable when trying to quantify the food consumed under natural conditions.

Quantitative studies on food consumption by marine organisms are an essential step towards understanding their ecological role in marine communities. In this context, daily ration models have been widely used in coastal and shallow waters to estimate the food con- 
sumed by fish (e.g. Durbin et al. 1983, Worobec 1984 , Macpherson 1985). Despite the interest of daily ration models in deep-water ecology, the application of these models to deep-water species is still limited. The food consumed by characteristic megafaunal species has been estimated in some deep-sea areas, particularly for demersal and mid-water fish species (Clarke 1978, Childress et al. 1980, Gorelova 1985, Bulman \& Koslow 1992. Pakhomov et al. 1996) Field estimates of food consumption in deep-water decapod crustaceans are scant; to our knowledge only Aristeus antennatus has been studied in this respect (Maynou \& Cartes 1997). Most of the papers cited focused on producing an estimate of food consumption for a single species. The comparison of food consumption among species has received some attention (Clarke 1978, Gorelova 1985, Koslow 1996, Pakhomov et al. 1996), and we believe that expanding the comparative approach among species belonging to the same taxon or within guilds can help in understanding the ecological role of each species within its community. To this end, Koslow (1996) compared the food consumption of morphologically disparate fishes (from migratory epipelagic species to benthic deep-water species), and synthesized the relationship between morphology, behavioral habits, metabolism and food consumption in deep-water fishes. He found that there is a gradient in mobility, metabolism and food consumption in the species that he examined, from benthic fishes living on the sea floor with low metabolic levels, mobility and food consumption, to highly active epipelagic fishes having a high metabolism and food consumption.

The objectives of our study were (1) to produce estimates of food consumption based on daily ration models for the dominant decapod crustaceans of the NW Mediterranean slope, (2) to relate the estimates obtained to the functional morphology of each species and to compare these relationships across species, and (3) to extend Koslow's (1996) results to deep-water decapod crustaceans from a biological and ecological perspective

\section{MATERIAL AND METHODS}

Data source and data treatment. The basic material for this study comes from 2 experimental surveys carried out on the NW Mediterranean continental slope off Barcelona (Spain) The first survey (DN-1) comprised 5 trawl locations around the position $41^{\circ} 07^{\prime} \mathrm{N}$, $02^{\circ} 03^{\prime} \mathrm{E}$ (610 to $710 \mathrm{~m}$ depth, middle slope). The survey was conducted between 13 and 14 July 1989, over an $18 \mathrm{~h}$ cycle. The second survey was conducted between 17 and 19 March 1994 around the position $41^{\circ} 00^{\prime} \mathrm{N}, 02^{\circ} 15^{\prime} \mathrm{E}$ (1178 to $1240 \mathrm{~m}$ depth, lower slope) and lasted $41 \mathrm{~h}$, with a total of 9 trawl hauls. In this survey, the sampling spanned almost $2 \mathrm{~d}$ and the samples were pooled over a $24 \mathrm{~h}$ notional day. In both surveys, the duration of trawling was set to $1 \mathrm{~h}$, and the time between trawl hauls varied from 2 to $5 \mathrm{~h}$. The environmental characteristics of the deep waters in the NW Mediterranean, including the depth strata sampled in both surveys, are stable throughout the year, with a constant temperature of $13.0 \pm 0.5^{\circ} \mathrm{C}$ below $200 \mathrm{~m}$ (Hopkins 1985).

The decapod crustaceans on the middle slope that were dominant in abundance and biomass were selected for stomach contents analysis. The species selected were the mesopelagic caridean shrimp Pasiphaea multidentata, the carideans Acanthephyra eximia, Plesionika acanthonotus and P. martia the polychelid lobster Polycheles typhlops and the red crab Geryon longipes. These 6 species together with the penaeid shrimp Aristeus antennatus (previously studied in Maynou \& Cartes 1997) accounted for $97.7 \%$ of the decapod crustacean biomass in the middle-slope depth stratum. The dominant decapod crustaceans on the lower slope are the caridean shrimps Acanthephyra eximia and Pontophilus norvegicus and the anomuran crab Munida tenuimana. These 3 species together with Geryon longipes and Aristeus antennatus accounted for $97.0 \%$ of the total decapod crustacean biomass in the lower-slope depth stratum.

A representative subsample of all the individuals of the selected species caught were measured [carapace length (CL) and carapace width (CW), in mm], sexed and weighed [g wet weight (WW)] onboard, and preserved in $70 \%$ alcohol for laboratory analysis. Summary data on the samples obtained in the 2 experimental surveys are shown in Table 1. The stomach contents of each specimen were removed and dried in an oven at $100^{\circ} \mathrm{C}$, for $24 \mathrm{~h}$. The stomach contents dry weight ( $g$ DW) thus obtained was used to compute the stomach fullness index as:

$$
F_{\text {wet }}=\underset{(\mathrm{WW})^{-1}}{(\mathrm{~g} \text { stomach contents } \mathrm{DW}) \cdot(100 \mathrm{~g} \text { predator }}
$$

The stomach fullness index was also expressed, for comparative purposes, as:

$$
\begin{aligned}
F_{\mathrm{dry}}= & (\mathrm{g} \text { stomach contents } \mathrm{DW}) \cdot(100 \mathrm{~g} \text { predator } \\
& \mathrm{DW})^{-1}
\end{aligned}
$$

using a standard conversion factor of $25 \mathrm{~g} \mathrm{DW} \cdot(100 \mathrm{~g}$ $W W)^{-1}$.

A 2-way ANOVA was used to reveal the possible effect of size or sex on stomach fullness $\left(F_{\text {wet }}\right)$ within species. When the stomach fullness was significantly different by sex or size ( 0.05 level of significance) for a given species, each statistically homogeneous group was treated separately and the daily ration was esti- 
mated independently for each group. Within each homogeneous group thus obtained, the existence of feeding peaks was tested by 1 -way ANOVA with the time of day as factor. The significant feeding peaks were isolated using Scheffé's post-hoc test (0.05 level of significance).

Daily ration methods. The methods and models for determination of daily ration in fish are reviewed in Bromley (1994) and Héroux \& Magnan (1996). In a previous work, we assessed their applicability to decapod crustaceans (Maynou \& Cartes 1997). Daily ration models assume that food is egested from the stomach according to an exponential function (Elliott \& Persson 1978, Bromley 1994) which includes a constant for gastric evacuation rate $(R)$. The value of $R$ can be obtained in the field under certain conditions (Bulman \& Koslow 1992, Héroux \& Magnan 1996) or by starvation experiments in the laboratory (Hill 1976, Sardà \& Valladares 1990, Héroux \& Magnan 1996). For deep-sea animals, it is impractical to undertake this kind of experiment in the laboratory; hence, an independent estimate of $R$ must be obtained before applying daily ration models Elliott \& Persson (1978) and Bromley (1994) concluded that $R$ is influenced primarily by the composition of food prey and by water temperature, while predator or prey size, meal size and feeding frequency are less important.

In our previous work on Aristeus antennatus (Maynou \& Cartes 1997), we obtained $R$ from temperaturebased models available in the literature (Durbin et al. 1983, Worobec 1984, Pakhomov et al. 1996). The values obtained for $R$ from these equations for a temperature of $13^{\circ} \mathrm{C}$ ranged from 0.172 to $0.192 \mathrm{~h}^{-1}$. On the other hand, based on the evacuation experiments by Sardà \& Valladares (1990) with Nephrops norvegicus in the laboratory at $13^{\circ} \mathrm{C}$, we calculated an experimental value of $R=0.179 \mathrm{~h}^{-1}$ (Maynou \& Cartes 1997), which is within the range of the estimates based on temperature equations. In their experiment, Sardà \& Valladares fed $N$. norvegicus 3 prey categories: the fish Engraulis encrasicolus, crangonid shrimps and polychaetes, simulating the basic food types of $N$. norvegicus' natural diet. We took this value of $R$ as appropriate in our computations of daily ration estimates for $A$. antennatus (Maynou \& Cartes 1997), Plesionika acanthonotus and Geryon longipes because these species feed on a variety of prey items (Lagardère 1977, Cartes 1993a, authors' unpubl. data) belonging to the same categories as in Sardà \& Valladares (1990), and they dwell in similar environmental conditions and are subject to the same temperature regime. For species feeding mainly on hard-shelled prey or fish remains (Acanthephyra eximia, Pasiphaea multidentata, Plesionika martia, Polycheles typhlops and Munida tenuimana; Cartes \& Abelló 1992, Cartes 1993a, b, authors' unpubl. data), we recalculated $R$ by pooling the categories 'Engraulis encrasicolus' and 'crangonids' in Sardà \& Valladares (1990), obtaining $R=0.150 \mathrm{~h}^{-1}$. For the species feeding almost solely on soft prey-i.e. Pontophilus norvegicus, which feeds exclusively on polychaetes - we obtained $R=0.312 \mathrm{~h}^{-1}$, from the prey category' 'polychaetes' in Sardà \& Valladares (1990).

An alternative method for estimating $R$ from our experimental data set, based on the $R_{\max }$ procedure (Héroux \& Magnan 1996), was also attempted. This method assumes the occurrence of a period of no feeding between 2 consecutive sampling times. Once the period of no feeding is identified, the stomach can be assumed to be exclusively egesting and $R$ can be computed from the difference between the initial and final stomach contents, following an exponential model. This procedure could only be applied to Geryon longipes, which has a well-marked feeding peak at dawn and feeds very little afterwards. The $R$ obtained

Table 1. Summary data of trawl samplings BT-1 (March 1994, lower slope) and DN-1 (July 1989, middle slope). N is the number of samples for each species, $T$ is the total number of individuals analyzed, and $X$ is the mean of number of individuals per sample. Size range and mean size of individuals in $\mathrm{mm}$ (CL). Sex ratio as percentage of females. Mean weight in $\mathrm{g}$

\begin{tabular}{|c|c|c|c|c|c|c|c|c|}
\hline & Sampling & $\mathrm{N}$ & $\mathrm{T}$ & $x$ & Size range & Mean size & Sex ratio & Mean weight \\
\hline Acanthephyra eximia & BT-1 & 7 & 88 & 13 & $17.0-47.0$ & 24.9 & 69.1 & 7.05 \\
\hline Pontophilus norvegicus & BT-1 & 7 & 198 & 28 & $4.8-12.0$ & 9.2 & 100.0 & 0.51 \\
\hline Munida tenuimana & BT-1 & 7 & 275 & 39 & $5.3-22.3$ & 16.0 & 58.2 & 3.13 \\
\hline Aristeus antennatus ${ }^{\mathrm{a}}$ & DN-1 & 5 & 165 & 33 & $19.2-52.8$ & 33.0 & 71.8 & 16.80 \\
\hline Acanthephyra eximia & DN-1 & 4 & 48 & 12 & $26.3-39.9$ & 31.2 & 21.7 & 12.46 \\
\hline Pasiphaea multidentata & DN-1 & 5 & 189 & 38 & $22.0-45.1$ & 30.6 & 66.5 & 7.24 \\
\hline Plesionika acanthonotus & DN-1 & 3 & 74 & 25 & $12.0-18.7$ & 14.2 & 60.8 & 2.54 \\
\hline Plesionika martia & DN-1 & 5 & 156 & 31 & $16.2-26.7$ & 21.4 & 47.4 & 7.18 \\
\hline Polycheles typhlops & DN-1 & 5 & 144 & 29 & $16.0-44.3$ & 31.8 & 84.1 & 10.51 \\
\hline Geryon longipes & $D N-1$ & 5 & 94 & 19 & $22.9-68.9$ & 56.9 & 77.7 & 104.98 \\
\hline
\end{tabular}


by this method was $0.183 \mathrm{~h}^{-1}$, which is close to $R=$ $0.179 h^{-1}$ found for species feeding on mixed prey categories.

The 3 most widely used models to compute the daily ration in fish are those of Eggers $(1977,1979)$, and Elliott \& Persson (1978). They were used to determine the daily ration of our decapod species, except that Pasiphaea multidentata was subjected to a different analysis (see below). These models are (see also Eggers 1977, 1979, Elliott \& Persson 1978, Pennington 1985, Bromley 1994, Héroux \& Magnan 1996):

Eggers (1977):

$$
C_{\text {(24E) }}=F_{24} R 24
$$

where $F_{24}$ is the mean stomach fullness index over $24 \mathrm{~h}$, as $F_{\text {wet }}$ or $F_{\text {dry. }}$. This model assumes that the weight of the stomach contents does not change between the beginning and the end of the study period.

Eggers (1979): When the last assumption cannot be met, Eggers (1979; see also Pennington 1985) proposed the corrected model:

$$
C_{(24 \mathrm{EC})}=C_{(24 \mathrm{E})}+\left(F_{t=24}-F_{t=0}\right)
$$

where $F_{t=24}$ and $F_{t}=0$ are the values of the stomach fullness index (as $F_{\text {wet }}$ or $F_{\text {dry }}$ ) at the end and at the beginning of the sampling period.

Elliott \& Persson (1978): The food consumed during the time interval $t_{3}$ is:

$$
C_{t_{1}}=\frac{\left(F_{t_{1}}-F_{t_{1}} \mathrm{e}^{-R t_{1}}\right) R t_{i}}{1-\mathrm{e}^{-R t_{1}}}
$$

and the daily ration is the sum of Eq. (3) over the $K$ time intervals considered:

$$
C_{\left(24 \mathrm{E} \& p_{i}\right.}=\sum_{j=1}^{K} C_{i_{i}}
$$

The assumptions of the Elliott \& Persson model are that food evacuation is exponential and that the rate of food consumption within each sampling interval is constant.

For the DN-1 sampling cycle $(18 \mathrm{~h})$ the values of. $C$ obtained by these models were multiplied by $4 / 3$ to obtain the daily ration over $24 \mathrm{~h}$.

The variance of each food consumption estimate $\left[C_{(24 E),} C_{24 E C)}\right.$ and $\left.C_{(24 E \& P]}\right]$ was computed following the randomization approach described in Maynou \& Cartes (1997). The variance is expressed as $2 \times$ standard error in order to give an approximate $95 \%$ confidence interval around the mean.

We applied an alternative approach to estimate the food consumption for Pasiphaea multidentata. It is known that this mesopelagic shrimp undertakes day/night migrations in the water column and feeds mainly near the surface at night (Cartes et al. 1993). Moreover, this behaviour is complicated by the fact that the large specimens ( $\mathrm{CL}>29 \mathrm{~mm}$ ) tend to remain near the bottom over the $24 \mathrm{~h}$ cycle, while it is mostly the smaller individuals which migrate (Cartes et al. 1993). The fraction of the population which feeds at night near the surface poses a problem for the application of daily ration methods, because they are not caught by the bottom trawl at dusk and night, and because when they become available to the trawl at dawn, their stomachs are mostly empty. To overcome these problems, we examined the actual stomach contents of $P$. multidentata and were able to discriminate between the fraction of individuals feeding on pelagic prey near the surface and thnse individuals preying on benthic items. We thus divided $P$. multidentata into a 'pelagic' fraction and a 'benthic' fraction, which were analyzed separately. We identified the prey remains in the stomachs of pelagic and benthic $P$. multidentata to the lowest practical taxonomic level. We then computed the wet weight of prey consumed by each fraction of $P$. multidentata based on length-to-weight curves for prey items (authors' unpubl. data). The wet weight of prey was then converted to dry weight using a factor of $25 \%$. The accuracy of this method for obtaining the stomach fullness index of $P$. multidentata is uncertain because some prey items were in an advanced stage of digestion and were difficult to assign to a taxon, but it can be used as a first approximation.

Multivariate analysis. The size spectrum, morphology, dietary composition, feeding habits and behaviour of the 9 species analyzed (including Aristeus antennatus) vary to a large extent (Cartes \& Abelló 1992, Cartes $1993 \mathrm{a}, \mathrm{b}, 1994$ ). The size spectrum of the 9 species studied indicated that the samples consisted mainly of adult specimens (Table 1). The morphology of the species varied from active swimmers, typically shrimps (the carideans Acanthephyra eximia, Pasiphaea multidentata and Plesionika spp., and the penaeid $A$. antennatus), to the slow-moving, epibenthic crabs (the anomuran Munida tenuimana and the brachyuran Geryon longipes). We introduced the accessory variabies swimming capability (Kt) and shape (ratio of CL to CW. CL/CW) to account for these disparate morphologies and behaviours. The swimming capability of decapod crustaceans in the NW Mediterranean was calculated by Cartes et al. (1994b) using a tiered suprabenthic sledge which sampled near-bottom organisms at 3 levels above the sea floor: $0.10-0.50 \mathrm{~m}, 0.55-0.95 \mathrm{~m}$ and $1.00-1.40 \mathrm{~m}$. Kt is a relative measure of abundance of each species at a given level of the suprabenthic sledge, yielding an approximation of their capability to swim off-bottom (see details in Cartes et al. 1994b).

The dietary composition and feeding habits of the species selected have been extensively studied in the NW Mediterranean (Cartes \& Abelló 1992, Cartes $1993 a, b, 1994$ ). From these sources we obtained the 
trophic diversity index $\left(H^{\prime}\right)$ and the mean number of prey in each stomach ( $\mathrm{Np}$ ) for each selected species. The proportion of full stomachs was estimated on a relative scale from 0 (empty) to 100 (full) from visual examination of our samples under a stereomicroscope prior to drying the stomach contents. For each species, the mean proportion of full stomachs (Mean F) was calculated by counting the proportion of individuals with full stomachs (fullness $\geq 75 \%$; see details in Cartes \& Abelló 1992 and Cartes 1993a, b, 1994). Mean F, H' and $\mathrm{Np}$ were used as proxy variables to account for variations in the diet and trophic strategy of each predator species.

The spatial distribution pattern (aggregate distribution, random distribution or avoidance among individuals) was characterized by Lloyd's spatial index (Lloyd 1967 in Hurlbert 1990), $I_{\mathrm{L}}$, from our middle- and lowerslope sampling. For each species, $I_{\mathrm{L}}$ is defined as:

$$
I_{\mathrm{L}}=\frac{1}{m}\left(\frac{s^{2}}{m}+m-1\right)
$$

where $m$ and $s^{2}$ are, respectively, the mean and the variance of the abundance (individuals $\times 10000 \mathrm{~m}^{-2}$ ) of each selected species. $I_{\mathrm{L}}$ near 0 indicates spatial avoidance among individuals and is typical of dispersed benthic or territorial organisms; $I_{\mathrm{L}}$ around 1 indicates random spatial distribution, while $I_{L}>1$ indicates that individuals aggregate to some extent, the absolute value of $I_{L}$ showing the strength of the spatial aggregation. Large values $>1$ are typical of animals forming shoals or high-density patches (Hurlbert 1990).

Finally, the variable $\log W W$ was used as a normalized measure of size. The values and sources of the proxy variables used in our analysis are given in Table 2.

We sought to determine the most important factors contributing to decapod daily ration by multivariate analysis of a data matrix formed by the daily ration of each species and the accessory variables. Principal Components Analysis (PCA) was employed to explore the multivariate relationships among variables. The solution of the PCA was rotated using the VARIMAX rotation technique to allow for interpretation of the principal components. Stepwise Multivariate Regression was used to determine which of the accessory variables explained significant portions of the variability in the daily ration of each decapod species studied. We deemed only those independent variables with partial $F$ significant at $\mathrm{p} \leq 0.05$ to be significant.

\section{RESULTS}

\section{Stomach fullness}

Two-way ANOVA on the stomach fullness indices $\left(F_{\text {wet }}\right)$ of our decapod species showed that only in Munida tenuimana was there a significant effect of sex in determining the stomach fullness $(\mathrm{p}=0.017)$. Hence, we estimated the food consumption of $M$. tenuimana separately for males and females. No size effect was detected in any of the species analyzed. $F_{\text {wet }}$ for each statistically homogeneous group at each sampling interval is shown in Fig. 1. A 1-way ANOVA with time of day as independent variable was performed on each species or homogeneous group to uncover possible feeding peaks or periodic feeding behaviour. Both males and females of $M$. tenuimana showed significant differences $(\mathrm{p}<0.05)$ in stomach fullness over the notional $24 \mathrm{~h}$ period. Males of $M$. tenuimana had 2 feeding peaks, one at dusk (around 18:00 h Greenwich Mean Time) and one at night (around 01:00 h GMT), although they were not significant according to a Scheffé's post-hoc test. Females of $M$. tenuimana did

Table 2. Ancillary variables used to define the mobility patterns, trophic preferences and spatial distribution of each selected species. Kt (swimming capabilıty) and $\mathrm{CL} / \mathrm{CW}$ (shape) are proxy variables for swimming behaviour and mobility; Mean $\mathrm{F}$ (mean number of individuals with full stomachs), $H^{\prime}$ (trophic diversity) and $\mathrm{Np}$ (mean number of prey items) for trophic behaviour;

$I_{L}$ (Lloyd's index of spatial dispersion) for spatial distribution. See text for computation of variables and literature sources

\begin{tabular}{|lccccccc|}
\hline & $\mathrm{Kt}$ & $\mathrm{CL} / \mathrm{CW}$ & $\log W \mathrm{~W}$ & Mean F & $H^{\prime}$ & Np & $I_{\mathrm{L}}$ \\
\hline Acanthephyra eximia (BT-1) & 0.76 & 2.39 & 0.83 & 30.2 & 3.92 & 2.9 & 2.66 \\
Pontophilus norvegicus & 0.14 & 1.38 & 0.17 & 11.6 & 1.97 & 1.3 & 1.86 \\
Munida tenuimana & 0.00 & 1.27 & 0.58 & 26.1 & 3.69 & 2.6 & 8.84 \\
Aristeus antennatus & 0.55 & 2.29 & 1.25 & 55.5 & 5.11 & 16.6 & 1.54 \\
Acanthephyra eximia (DN-1) & 0.76 & 2.16 & 1.13 & 29.7 & 3.66 & 2.0 & 2.66 \\
Pasiphaea multidentata (pelagic) & 0.86 & 3.05 & 1.01 & 50.0 & 2.76 & 1.8 & 6.02 \\
Pasiphaea multidentata (benthic) & 0.60 & 3.01 & 0.87 & 6.8 & 3.46 & 2.3 & 6.02 \\
Plesionika acanthonotus & 0.5 & 1.61 & 0.55 & 21.49 & 3.74 & 1.9 & 2.81 \\
Plesionika martia & 0.69 & 1.92 & 0.91 & 38.18 & 3.5 & 1.7 & 3.26 \\
Polycheles typhlops & 0.44 & 1.38 & 1.06 & 12.19 & 4.31 & 2.2 & 1.30 \\
Geryon longipes & 0.00 & 0.84 & 2.02 & 7.01 & 4.19 & 3.3 & 0.10 \\
\hline
\end{tabular}



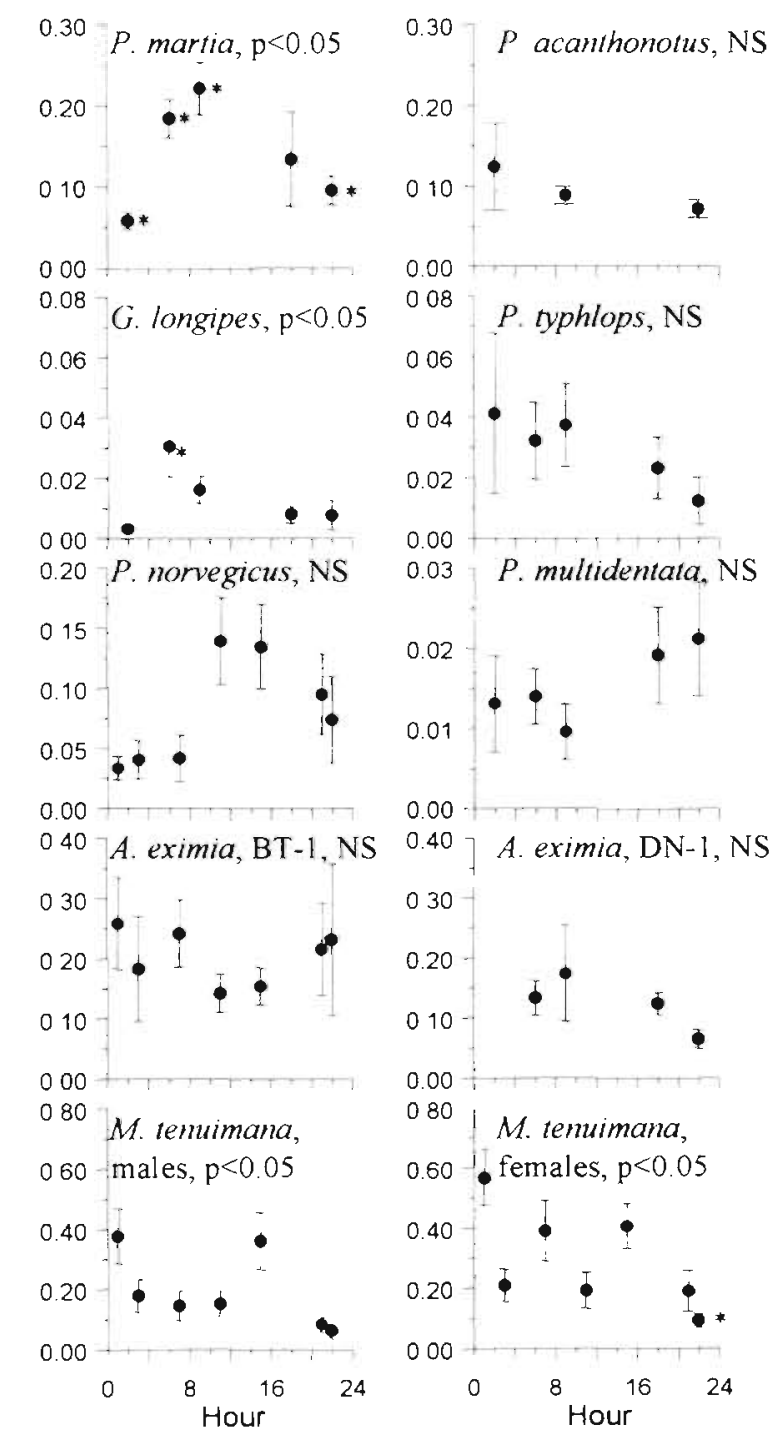

Fig. 1. Diel variations in stomach fullness ( $g$ food DW per 100 $g$ of predator WW, \% DW/WW) for 8 species of crustacean decapods. NS and $p<0.05$ indicate non-significant and significant variations in the daily food-consumption pattern based on a 1.-way ANOVA with hour as independent variable. Asterisks identify the significant samples using a post-hoc Scheffé test. For Acanthephyra eximia, DN-1 and BT-1 identify the middle- and lower-slope samplings

not show a clear feeding periodicity, but $F_{\text {wet }}$ of the early night sample (around 22:00 h GMT) was significantly lower than the other samples according to a Scheffés post-hoc test. Geryon longipes showed a significant dawn (around 06:00 h GMT) feeding peak according to a combined 1-way ANOVA and Scheffé's post-hoc test. Likewise, Plesionika martia showed a significant dawn to morning feeding peak. On the other hand, Pontophilus norvegicus is clearly a daytime feeder, but the 1-way ANOVA was not significant. The remaining species can be considered continuous feeders over the notional $24 \mathrm{~h}$ period. Note also that the stomach fullness of Pasiphaea multidentata was very low $\left(F_{\text {wet }}=0.01\right.$ to $\left.0.03 \%\right)$ and it peaked towards dusk, although it was not significant. Detailed study of its stomach contents indicated that the larger individuals of the population feeding on benthic organisms remained available to the trawl during the $18 \mathrm{~h}$ cycle, while the smaller, pelagic-feeding fraction was available to the trawl at dawn and morning

\section{Daily ration}

The daily rations computed for each species using Eqs. (1) to (4) are shown in Table 3, together with the approximate value of actual ration derived for Pasiphaea multidentata and the food consumption for Aristeus antennatus (from Maynou \& Cartes 1997). The daily ration was computed as $\mathrm{g}$ DW consumed by $100 \mathrm{~g}$ of predator WW (\% DW/WW, Table 3a) and then transformed to $\mathrm{g}$ DW consumed by $100 \mathrm{~g}$ predator DW $(\%$ DW/DW, Table 3b; see 'Data source and data treatment' in 'Material and methods') to ease comparison with values for fish species reported in the literature (see 'Discussion'). For species with no marked feeding peaks, each of the 3 methods produced approximately the same daily ration values (Table 3 ). For species with marked feeding peaks, the methods of Eggers (1979) and Elliott \& Persson (1978) yielded similar values, while Eggers' (1977) model typically produced higher values. Based on the theoretical considerations of each of the models (see Eqs. 1 to 4), we took the value of food consumption given by the Eggers (1977) method as adequate for species with no marked feeding peaks (Acanthephyra eximia, Pontophilus norvegicus, Plesionika acanthonotus and Polycheles typhlops). For the species showing marked feeding peaks ( $A$. antennatus, Munida tenuimana, Plesionika martia and Geryon longipes), the values of daily ration obtained by the Eggers (1979) method were retained. According to Boisclair \& Leggett (1988), this method is more robust for use with field data than the Elliott \& Persson (1978) method.

Food consumption varied by an order of magnitude, from the reptant species Polycheles typhlops and Geryon longipes, with daily rations below $0.1 \%$ DW/WW, to the mesopelagic migrator Pasiphaea multidentata, with a daily ration of $1.2 \% \mathrm{DW} / \mathrm{WW}$, for the pelagic individuals (Table 3a). Comparison of food consumption by $P$. multidentata obtained by the actual ration approach and the daily ration approach showed that the latter underestimated the food consumption by an order of magnitude.

The comparison between the 2 data sets (BT-1 and DN-1) showed that the species from the lower slope con- 
Table 3. (a) Estimates of daily ration ( $\%$ DW/WW \pm 2 SE) for each statistically homogeneous group, by 3 different models. $C_{(24 E)}$ (Eggers 1977), $C_{124 E C)}$ (Eggers 1979), C 124 Esp) (Elliott \& Persson 1978). Actual ration is the ration determined from exhaustive analysis of the stomach contents. (b) Estimates of daily ration from (a) converted to \% DW/DW ( \pm 2 SE). Bold indicates the values of daily ration retained based on theoretical considerations of the models

\begin{tabular}{|c|c|c|c|c|}
\hline & $C_{(24 \mathrm{E})}$ & $C_{(24 E C)}$ & $C_{(24 E \& P)}$ & Actual ration \\
\hline \multicolumn{5}{|l|}{ (a) Daily ration ( $\% \mathrm{DW} / \mathrm{WW}$ ) } \\
\hline Acanthephyra eximia (BT-1) & $0.750 \pm 0.108$ & $0.722 \pm 0.126$ & $0.582 \pm 0.185$ & \\
\hline Pontophilus norvegicus & $0.680 \pm 0.139$ & $0.720 \pm 0.142$ & $0.635 \pm 0.110$ & \\
\hline Munida tenuimana (males) & $0.722 \pm 0.132$ & $0.407 \pm 0.143$ & $0.302 \pm 0.168$ & \\
\hline Munida tenuimana (females) & $1.086 \pm 0.140$ & $0.610 \pm 0.159$ & $0.457 \pm 0.178$ & \\
\hline Aristeus antennatus ${ }^{a}$ & $0.223 \pm 0.013$ & $0.177 \pm 0.016$ & $0.130 \pm 0.018$ & \\
\hline Acanthephyra eximia (DN-1) & $0.435 \pm 0.075$ & $0.365 \pm 0.090$ & $0.257 \pm 0.089$ & \\
\hline Pasiphaea multidentata (pelagic) & $0.037 \pm 0.013$ & $0.077 \pm 0.018$ & $0.074 \pm 0.017$ & 1.205 \\
\hline Pasiphaea multidentata (benthic) & $0.057 \pm 0.015$ & $0.053 \pm 0.017$ & $0.046 \pm 0.015$ & 0.729 \\
\hline Plesionika acanthonotus & $0.323 \pm 0.119$ & $0.322 \pm 0.116$ & $0.283 \pm 0.096$ & \\
\hline Plesionika martia & $0.442 \pm 0.052$ & $0.479 \pm 0.062$ & $0.508 \pm 0.057$ & \\
\hline Polycheles typhlops & $0.096 \pm 0.043$ & $0.093 \pm 0.045$ & $0.077 \pm 0.046$ & \\
\hline Geryon longipes & $0.061 \pm 0.015$ & $0.065 \pm 0.017$ & $0.054 \pm 0.015$ & \\
\hline \multicolumn{5}{|l|}{ (b) Daily ration (\% DW/DW) } \\
\hline Acanthephyra eximia (BT-1) & $3.000 \pm 0.431$ & $2.888 \pm 0.503$ & $2.328 \pm 0.742$ & \\
\hline Pontophilus norvegicus & $2.720 \pm 0.557$ & $2.880 \pm 0.569$ & $2.540 \pm 0.441$ & \\
\hline Munida tenuimana (males) & $2.888 \pm 0.526$ & $1.628 \pm 0.572$ & $1.208 \pm 0.671$ & \\
\hline Munida tenuimana (females) & $4.344 \pm 0.561$ & $2.440 \pm 0.635$ & $1.828 \pm 0.707$ & \\
\hline Aristeus antennatus ${ }^{\mathrm{a}}$ & $0.892 \pm 0.056$ & $0.708 \pm 0.062$ & $0.520 \pm 0.070$ & \\
\hline Acanthephyra eximia (DN-1) & $1.740 \pm 0.300$ & $1.460 \pm 0.359$ & $1.028 \pm 0.354$ & \\
\hline Pasiphaea multidentata (pelagic) & $0.148 \pm 0.053$ & $0.308 \pm 0.074$ & $0.296 \pm 0.070$ & 4.820 \\
\hline Pasiphaea multidentata (benthic) & $0.228 \pm 0.062$ & $0.212 \pm 0.070$ & $0.184 \pm 0.062$ & 2.916 \\
\hline Plesionika acanthonotus & $1.292 \pm 0.474$ & $1.288 \pm 0.465$ & $1.132 \pm 0.386$ & \\
\hline Plesionika martia & $1.768 \pm 0.208$ & $1.916 \pm 0.247$ & $2.032 \pm 0.228$ & \\
\hline Polycheles typhlops & $0.384 \pm 0.170$ & $0.372 \pm 0.180$ & $0.308 \pm 0.184$ & \\
\hline Geryon longipes & $0.244 \pm 0.062$ & $0.260 \pm 0.066$ & $0.216 \pm 0.061$ & \\
\hline
\end{tabular}

sumed more food than the species of the middle slope. This is especially clear for Acanthephyra eximia, which was sampled in both areas: the deeper fraction of the population had a daily ration which was almost double $(0.750 \%$ DW $/ W W)$ that of the middle slope population ration $(0.435 \%$ DW/WW). Pontophilus norvegicus and Munida tenuimana also had relatively high consumption values (Table 3). In $M$. tenuimana food consumption in females was higher than in males (Table 3)

\section{Multivariate analysis}

A PCA was performed on the data given in Table 2 and the bold-face values of daily ration in Table $3 a$ $\left(F_{\text {wet }}\right)$. The plot of the factor loadings of each variable on the 2 principal components is shown in Fig. 2. The first component (accounting for $37.4 \%$ of the variance) was found to be inversely related to the variables $\mathrm{Np}$, $H^{\prime}$ and $\log W W$, which are proxy variables for trophic strategy and size. The second component $(29.0 \%$ of the variance) represented a combination of Mean F,
CL/CW and Kt, i.e. the mean proportion of full stomachs, the shape and the swimming capability. The index of spatial distribution $\left(I_{L}\right)$ and the daily ration lay between the 2 first components.

A forward stepwise multiple regression was performed taking daily ration as the dependent variable and the remaining variables as independent (explanatory) variables (Table 4 ). This statistical technique identified CL/CW (shape) and $H^{\prime}$ (trophic diversity) as explanatory variables ( $p$-value of $F$ statistic smaller than 0.05). Streamlined species (high CL/CW ratio) with relatively low $H^{\prime}$, such as the natantian decapods Pasiphaea multidentata, Acanthephyra eximia and Plesionika spp., had higher daily rations. At the other end of the spectrum, the epibenthic, stocky Polycheles typhlops and Geryon longipes that feed on varied prey had the lowest daily rations. The swimming capability $(\mathrm{Kt})$ was not retained in the regression, probably because shape (CL/CW ratio) has a higher explanatory power, but both variables are closely related in the sense that they are proxy variables for mobility pattern and habits (benthic, nektobenthic and mesopelagic). 


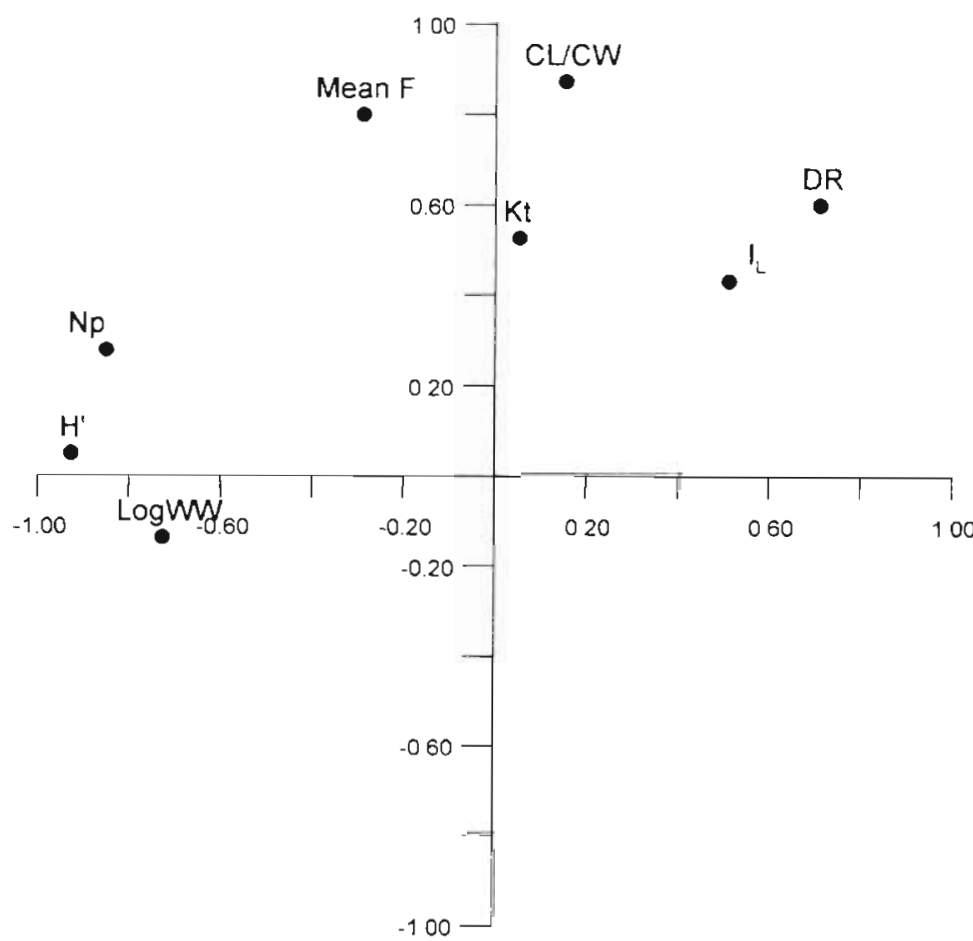

Fig. 2. Plot of factor loadings of the PCA analysis using the data matrix of daily ration (DR in \% DW/WW) in Table 3 a (boldface values) and ancillary variables in Table 2 . See text for definition of varıables

Pasiphaea multidentata followed a diel feeding cycle that precluded the estimation of food consumption from daily ration models. In these cases, a more straightforward approach, albeit more time-consuming, is to identify the partially digested prey remains to the lowest taxonomic level and try to reconstruct the biomass of prey ingested. The accuracy of this method is uncertain, but it can be used as an approximation of the actual food consumed by a problematic species, such as $P$. multidentata. The inaccuracy of this method originates in the possibility of either erroneously accounting for food items from previous digestions (such as otoliths and other hard parts which have a long residence time in the predator's stomach) or, conversely, missing fragile or soft prey which may have been digested between any 2 samples. However, in our previous paper (Maynou \& Cartes 1997) we compared this method with the daily ration method and found that both methods yielded close estimates of the food consumed by Aristeus antennatus.

It is important to test for sex or size influence on the index of stomach fullness, as different fractions of the population may have different daily rations. In our study, females of Munida

A general equation for estimating daily ration (in \% DW/WW) in decapod crustaceans of the NW Mediterranean (at $13^{\circ} \mathrm{C}$ ), based on field measurements of CL/CW and $H^{\prime}$, is given in Table 4 . Note that while $\mathrm{CL} / \mathrm{CW}$ is relatively easy to measure, $H^{\prime}$ requires the identification of the prey items in the stomach to a low taxonomic level.

\section{DISCUSSION}

As we indicated in an earlier study (Maynou \& Cartes 1997), daily ration methods originally developed for finfish species are fully applicable to decapod crustaceans. For continuously feeding species such as Acanthephyra eximia, Pontophilus norvegicus, Plesionika acanthonotus and Polycheles typhlops the method of Eggers (1977) is adequate. For species showing marked feeding peaks, we followed in our approach Boisclair \& Leggett (1988), who recommended the use of the Eggers (1979) method because it is more robust for use with field data (where the direct estimation of $R$ is not practical). However, special care must be exercised when dealing with species whose behaviour may make them unavailable to the sampling gear at given periods of the day. In our study, a fraction of the population of the mesopelagic tenuimana from the lower slope (March) had a higher daily ration than males. At this time of the year (early spring), females of $M$. tenuimana are in a resting, postmolt stage of their reproductive period (Dr P. Abelló pers. comm.). Thus, the higher food requirements of $M$. tenuimana females at this time of the year could be explained by the increased metabolic demands of growth prior to the onset of oogenesis.

Our daily ration estimates for 9 species of decapod crustaceans together with a multivariate analysis of the bio-ecological characteristics of these species allowed us to identify a clear pattern of food consumption by

Table 4. Results of forward stepwise regression of daily ration (DR) (boldface values in Table 3a) on explanatory variables (Table 2). An explanatory variable entered into the model when its partial $F$ was significant at the probability level 0.05 . Intercept of multivariate regression: $0.814(\mathrm{p}=0.017)$. A general equation for predicting daily ration in decapods in the NW Mediterranean, at a constant temperature of $13^{\circ} \mathrm{C}$, is: $\mathrm{DR}=0.814+0.217 \mathrm{CL} / \mathrm{CW}-0.252 \mathrm{H}$

\begin{tabular}{|lrr|}
\hline & CL/CW & \multicolumn{1}{c|}{$H^{\prime}$} \\
\hline Fstatistic & 19.973 & 8.316 \\
p-value & 0.004 & 0.028 \\
Slope of multivariate regression & 0.217 & -0.252 \\
p-level of slope & 0.022 & 0.004 \\
\hline
\end{tabular}


deep-water crustacean species of the middle slope. Actively swimming species with low trophic diversity had higher daily rations than benthic, reptant decapods. Nektobenthic species (e.g. those hovering above the sea floor feeding on benthic prey) showed intermediate food consumption. This pattern is illustrated for our decapod species in Fig. 3, where a plot of the daily ration (in \% DW/DW) of each species arranged by relative mobility is shown (ranked by $\mathrm{CL} / \mathrm{CW}$ ). On the middle slope (Fig. 3, left), Geryon longipes and Polycheles typhlops, which are reptantian species, have very low daily rations (below $0.5 \%$ DW/DW), while the natantian nektobenthic species have intermediate daily rations (ranging from 0.5 to $2.0 \% \mathrm{DW} / \mathrm{DW}$ ) and the mesopelagic Pasiphaea multidentata has an actual ration which ranges from 2.9 to $4.8 \% \mathrm{DW} / \mathrm{DW}$. On the lower slope, however, the range of daily rations for the reptantian Munida tenuimana encompasses the daily rations of the natantians Pontophilus norvegicus and Acanthephyra eximia (Fig. 3, right).

The pattern of increasing food consumption with increasing relative mobility is equivalent to that identified by Koslow (1996) in a recent review of studies on metabolism and daily ration in deep-water fishes. This author found that dispersed, slow-moving deep-sea fish had low metabolic rates and low food consumption, while aggregatory, strong swimmers such as the orange roughy Hoplostethus atlanticus, mesopelagic migrators (e.g. myctophid fish) and epipelagic species (sardine, anchovy) had progessively higher metabolic rates and daily rations. Although data on metabolic rates of deep-water decapods are scant, oxygen consumption by deep-water decapods in the Mediterranean was found to be higher in natantian than in reptantian species (Company 1995).

For comparative purposes, Table 5 presents some values of daily ration obtained for deep-water and epipelagic fish, based on literature sources. The dis-

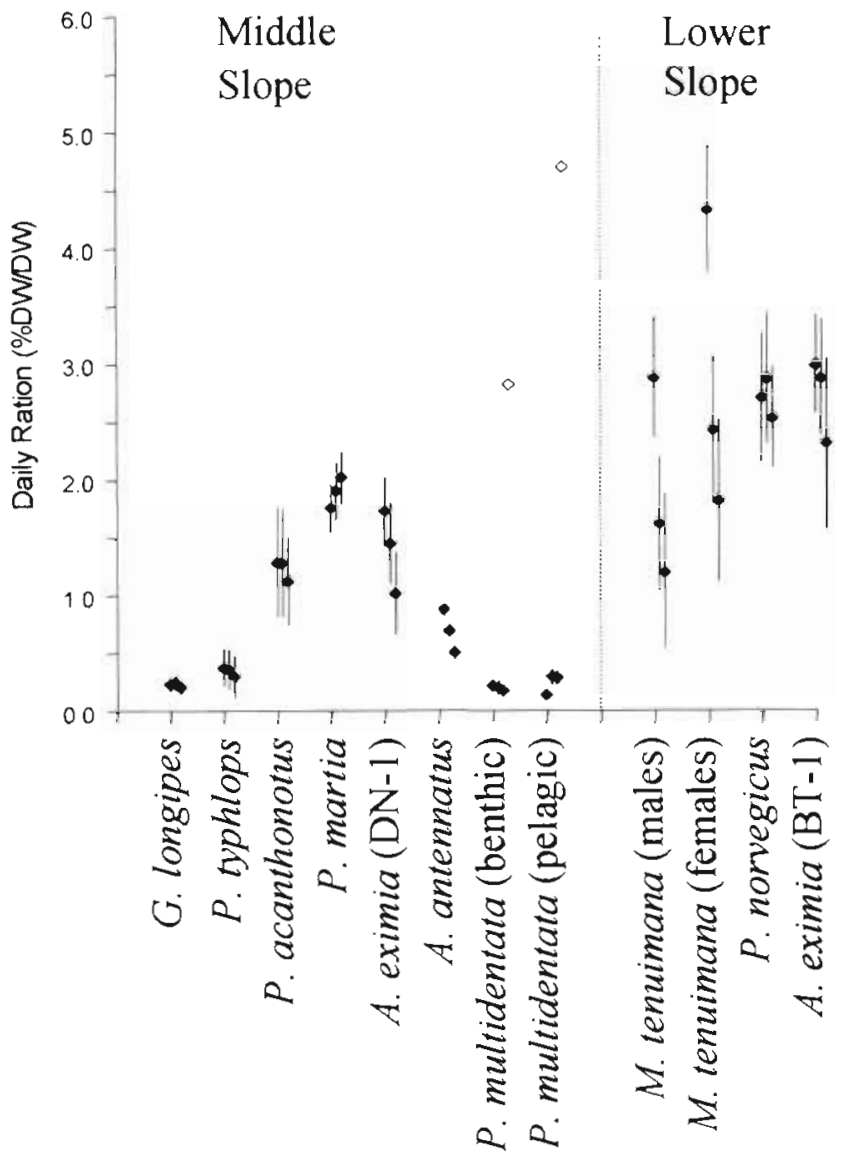

Fig. 3. Daily rations (\% DW/DW) of decapod species studied arranged according to relative mobility (CL/CW ratio) for the middle-slope and lower-slope samples. (0) Daily ration estimates obtained by direct analysis of stomach contents in Pasiphaea multidentata

persed, benthic fishes and the bathypelagic nonmigrators show daily rations generally below $1 \%$ WW/WW (Childress et al. 1980, Macpherson 1985,

Table 5. Daily rations of fishes arranged according to relative swimming ability. All daily rations are field estimates based on the same approach utilized in this paper, except for (6) which were obtained using an energy budget approach. Literature sources in parentheses. (1) Walleye pollock Theragra calcogramma from Dwyer et al. (1987); (2) Lophius upsicephalus (dispersed, benthic), Coelorhynchus fasciatus and Helicolenus dactylopterus (bathypelagic, non-migrators), range for 2 years, from Macpherson (1985); (3) Danaphos ocelatus (Myctophidae) from Clarke (1978); (4) range for 3 myctophid species from Clarke (1978); (5) range for 2 bathylagid species, Gorelova (1985); (6) Childress et al. (1980); (7) juvenile and adult Hoplostethus atlanticus from Bulman \& Koslow (1992); (8) range for European anchovy Engraulis encrasicolus from Tudela \& Palomera (1995); (9) range for antarctic and subantarctic Myctophidae (lower) and temperate and subtropical Myctophidae (higher) from Pakhomov et al. (1996)

\begin{tabular}{|c|c|c|}
\hline & Daily ration (\% DW/DW) & Daily ration ( $\%$ WW/WW) \\
\hline Dispersed, benthic & & $0.09-0.59(1), 0.55-1.60(2)$ \\
\hline Bathypelagic, non-migrators & $1.9(3)$ & $0.68(6), 0.07-1.30(2)$ \\
\hline Aggregate, benthic & $0.9-1.15(7)$ & \\
\hline Bathypelagic migrators & $0.2-1.5(5)$ & \\
\hline Mesopelagic & $4.3-6.5(4), 0.8-8.1(5), 0.24-2.32(9)$ & $0.87(6)$ \\
\hline Epipelagic & $3.6(6), 3.7-3.92(8)$ & \\
\hline
\end{tabular}


Dwyer et al. 1987), while epipelagic species such as sardine or anchovy have a 4 -fold increase in daily ration (rightmost column in Table 5; Childress et al. 1980, Tudela \& Palomera 1995).

The influence of temperature on the pattern discussed here is uncertain. The constant temperature regime in our study area $\left(13 \pm 0.5^{\circ} \mathrm{C}\right.$ below $200 \mathrm{~m}_{i}$ Hopkins 1985) means our estimates of daily ration are free of temperature influence. However, the daily rations for fishes summarized in Table 5 could be subject to temperature influence. For example, Pakhomov et al. (1996) found that Antarctic and subantarctic myctophids had lower rations ( 0.24 to $0.75 \%$ DW/DW) than temperate and subtropical myctophids (0.90 to $2.32 \%$ DW/DW), while Gorelova (1985) found that the Antarctic Bathylagus gracilis had a higher ration $(0.8$ to $1.5 \% \mathrm{DW} / \mathrm{DW})$ than the temperate $B$. pacificus $(0.2$ to $1.0 \%$ DW/DW)

Our finding that daily ration decreases with trophic diversity could be explained by the fact that active swimmers, and especially mesopelagic migrators with higher daily rations, have a more specialized diet given that they feed on mobile prey and are thus visual predators. Conversely, reptantian benthic and nektobenthic species, with lower rations, have a less specialized diet and thus higher trophic diversity (Cartes 1998). Aristeus antennatus is an extreme case in this sense: its daily ration is relatively low for a highly natatory organism, but this can perhaps be explained by its wide trophic spectrum (Cartes 1994).

A comparison of the daily rations of deep-water fishes (Table 5, middle column) and deep-water crustaceans with respect to dry weight (Table $3 \mathrm{~b}$, boldface values) suggests that highly mobile fish have daily rations similar to those of decapod crustaceans. For example, mesopelagic myctophids (Clarke 1978) and bathylagids (Gorelova 1985), which have a migrating behaviour similar to that of Pasiphaea multidentata, consume around $4.5 \% \mathrm{DW} / \mathrm{DW}$, which is very close to the value reported here for the pelagic fraction of $P$. multidentata populations $(4.8 \%$ DW/DW $)$. On the other hand, fish from deeper waters, such as bathypelagic fish (below $1000 \mathrm{~m}$ depth), have daily rations generally below $2.0 \%$ DW/DW (Table 5, middle column; Clarke 1978, Gorelova 1985), while our lowerslope decapods (1200 to $1300 \mathrm{~m}$ depth) have daily rations greater than $2.0 \%$ DW/DW

Regarding the depth-related aspects of food consumption, our results are not conclusive. Some evidence (Torres et al. 1979) indicates that bathypelagic fish generally consume less food than shallower fish species, possibly due to their lower metabolism rather than to decreased growth rate. However our results show an apparent higher daily ration for lower-slope decapods compared to middle-slope decapods (Fig. 3).
Although our results seem to contradict the findings of Torres et al. (1979), we cannot provide conclusive evidence on this aspect because of the uncertain influence of seasonality on deep-water biological processes. Our lower-slope samples were obtained in spring, when surface primary production regularly occurs in the studied area (Estrada 1991). Furthermore, some results obtained at depths around 1200 to $1300 \mathrm{~m}$ suggest a secondary peak of biological production at that level, as indicated by the peak of benthopelagic fish biomass detected in our study area (Stefanescu et al. 1994). Other studies point to important seasonal variations in fish daily rations (e.g. Worobec 1984, Macpherson 1985), indicating that further studies are needed at appropriate spatio-temporal scales to produce an accurate picture of food consumption patterns in megafaunal deep-sea species.

Acknowledgements. We thank Dr Sergi Tudela for critical reading of an earlier version of the manuscript. We thank all the people participating in the DN and BT cruises, especially Dr F. Sardà, for providing invaluable advice during the surveys. This study was partially funded by the 'Consejo Superior de Investigaciones Cientificas' of the Spanish government.

\section{LITERATURE CITED}

Boisclair D, Leggett WC (1988) An in situ experimental evaluation of the Elliott and Persson and the Eggers models for estimating fish daily ration. Can $J$ Fish Aquat Sci 45: $138-145$

Bromley PJ (1994) The role of gastric evacuation experiments in quantifying the feeding rates of predatory fish. Rev Fish Biol Fish 4:36-66

Bulman CM, Koslow JA (1992) Diet and food consumption of a deep-sea fish, orange roughy Hoplostethus atlanticus (Pisces: Trachichthyidae), off southeastern Australia. Mar Ecol Prog Ser 82:115-129

Cartes JE (1993a) Diets of deep-water pandalid shrimps on the Western Mediterranean slope. Mar Ecol Prog Ser 96: $49-61$

Cartes JE (1993b) Diets of two deep-sea decapods: Nematocarcinus exilis (Caridea: Nematocarcinidae) and Munida tenumana (Anomura: Galatheidae) on the Western Mediterranean slope. Ophelia 37:213-229

Cartes JE (1994) Influence of depth and season on the diet of the deep-water aristeid Aristeus antennatus along the continental slope (between 400 to $2300 \mathrm{~m}$ ) in the Catalan Sea (western Mediterranean). Mar Biol 120:639-648

Cartes JE (1998) Feeding strategies and partition of food resources in deep-water decapod crustaceans (between 400-2300 m). J Mar Biol Assoc UK 78:1-16

Cartes JE, Abelló P (1992) Comparative feeding habits of polychelid lobsters in the Western Mediterranean deepsea communities. Mar Ecol Prog Ser 84:139-150

Cartes JE, Company JB, Maynou F (1994a) Deep-water decapod crustaceans communities in the Northwestern Mediterranean: influence of submarine canyons and season. Mar Biol 120:221-230

Cartes JE, Sardà F (1992) Abundance and diversity of decapod crustaceans in the deep-Catalan Sea (Western 
Mediterranean). J Nat Hist 26:1305-1323

Cartes JE, Sardà F, Company JB, Lleonart J (1993) Day-night migrations by deep-sea decapod crustaceans in experimental samplings in the Western Mediterranean sea. J Exp Mar Biol Ecol 171:63-73

Cartes JE, Sorbe JC, Sardà F (1994b) Spatial distribution and swimming activity of deep-sea decapods and euphausiids near the bottom in the NW Mediterranean. J Exp Mar Biol Ecol 179:131-144

Childress JJ, Taylor SM, Cailliet GM, Price MH (1980) Patterns of growth, energy utilization and reproduction in some meso- and bathypelagic fishes off Southern California. Deep-Sea Res 20:1093-1109

Clarke TA (1978) Diel feeding patterns of 16 species of mesopelagic fishes from Hawaiian waters. Fish Bull US 76 . $495-513$

Company JB (1995) Estudi comparatiu de les estratègres biològiques dels crustacis decàpodes de la Mar Catalana. $\mathrm{PhD}$ thesis, Univ de Barcelona

Durbin EG, Durbin AG, Langton RW, Bowman RE (1983) Stomach contents of silver hake, Merluccius bilinearis, and Atlantic cod, Gadus morhua, and estimation of their daily rations. Fish Bull US 81(3):437-454

Dwyer DA, Bailey KM, Livingston PA (1987) Feeding and daily ration of Walleye Pollock (Theragra chalcogramma) in the Eastern Bering Sea, with special reference to cannibalism. Can J Fish Aquat Sci 44:1972-1984

Eggers DM (1977) Factors in interpreting data obtained by diel sampling of fish stomachs. J Fish Res Board Can 34 : 290-294

Eggers DM (1979) Comments on some recent methods for estimating food consumption by fish. J Fish Res Board Can 36:1018-1019

Elliott JM, Persson L (1978) The estimation of daily rates of food consumption for fish. J Anin Ecol 47:977-991

Estrada M (1991) Phytoplankton assemblages across a NW Mediterranean front: changes from winter mixing to spring stratification. In: Ros JD, Prat N (eds) Homage to Ramon Margalef; or, Why there is such pleasure in studying nature. Oecol Aquat 10:157-185

Gage JD, Tyler PA (1991) Deep-sea biology. Cambridge University Press, Cambridge

Gorelova TA (1985) Assessment of the daily ration of mesoand bathypelagic fishes of the family Bathylagidae. J Ichthyol 25:155-160

Héroux D, Magnan P (1996) In situ determination of food daily ration in fish: review and field evaluation. Environ Biol Fish 46:61-74

Editorial responsibility: Otto Kinne (Editor),

Oldendorf/Luhe, Germany
Hill BJ (1976) Natural food, foregut clearance-rate and activity of the crab Scylla serrata. Mar Biol 34:109-116

Hopkins TS (1985) Physics of the sea. In: Margalef R (ed) Key environments: Western Mediterranean. Pergamon Press, New York, p 100-125

Hurlbert SH (1990) Spatial distribution of the montane unicorn. Oikos 58:257-271

Koslow JA (1996) Energetic and life-history patterns of deepsea benthic, benthopelagic and seamount-associated fish. J Fish Biol 49(Suppl A):54-74

Lagardère JP (1977) Recherches sur le régıme alimentaire des décapodes benthiques de la pente continentale de l'Atlantique nordoccidental (Golfe de Gascogne et Maroc). In: Keegan BF, Ceidigh PO, Boaden PSJ (eds) Biology of benthic organisms. Pergamon Press, New York, p 397-408

Macpherson E (1985) Daily ration and feeding periodicity of some fishes of the coast of Namibia. Mar Ecol Prog Ser 26: $253-260$

Maynou F. Cartes JE (1997) Field estimation of daily ration in deep-sea shrimp Aristeus antennatus (Crustacea: Decapoda) in the western Mediterranean. Mar Ecol Prog Ser 153:191-196

Pakhomov EA, Perissinotto R, McQuaid CD (1996) Prey composition and daily rations of myctophid fishes in the Southern Ocean. Mar Ecol Prog Ser 134:1-14

Pennington $M$ (1985) Estımating the average food consumption by fish in the field from stomach contents data. Dana 5:81-86

Sardà F, Valladares FJ (1990) Gastric evacuation of different foods by Nephrops norvegicus (Crustacea: Decapoda) and estimation of soft tissue ingested, maximum food intake and cannibalism in captivity. Mar Biol 104:25-30

Stefanescu C. Morales-Nin B, Massutí E (1994) Fish assemblages on the slope in the Catalan Sea (western Mediterranean): influence of a submarine canyon. J Mar Biol Assoc UK 74:499-512

Torres JJ, Belman BW, Childress JJ (1979) Oxygen consumption rates of midwater fishes as a function of depth of occurrence. Deep-Sea Res 26:185-197

Tudela S, Palomera I (1995) Diel feeding intensity and daily ration in the anchovy Engraulis encrasicolus in the northwest Mediterranean Sea during the spawning period. Mar Ecol Prog Ser 129:55-61

Worobec MN (1984) Field estimates of the daily ration of winter flounder, Pseudopleuronectes americanus (Walbaum), in a southern New England salt pond. J Exp Mar Biol Ecol $77: 183-196$

Submitted: February 24, 1998; Accepted: May 29, 1998 Proofs received from author(s): August 31, 1998 